\title{
Effects of propranolol in a case of orthostatic hypotension
}

\author{
GREGORIO BREVETTI, MASSIMO CHIARIELLO, GIUSEPPE LAVECCHIA, \\ AND FRANCO RENGO
}

\author{
From the Istituto di Patologia Speciale Medica-II Facolta' di Medicina e Chirurgia-Universita' di Napoli, \\ Via Sergio Pansini 5, 80131 Napoli, Italia
}

SUMMARY In a hypertensive patient with orthostatic hypotension, the changes in several haemodynamic indices with respect to posture were evaluated. In the upright position, systemic blood pressure was reduced as compared with the supine position, and peripheral vasodilatation was present, as shown by an increase in Jantsch's index of the impedance plethysmographic tracings. Systolic time intervals remained unchanged with changes in posture. Propranolol $10 \mathrm{mg}$ intravenously brought the response to normal. In fact, after beta-blockade in the standing position the blood pressure remained unchanged and normal peripheral vasoconstriction was observed. Similar results were seen during atrial pacing at a constant heart rate of 130 beats/minute. In this patient, propranolol appears to normalise the response to the posture change, by restoring normal vasoconstriction in the upright position.

Orthostatic hypotension has been classically defined as a reduction in arterial pressure on standing. This uncommon disorder is probably related to sympathetic nervous dysfunction induced either by certain diseases, such as diabetes mellitus (SharpeySchafer and Taylor, 1960), hypertension (Drenick, 1957; Lewis and Dunn, 1967; Boźović et al., 1970) and other disorders (Ibrahim et al., 1975), or by different drug treatments (Parra and Vidrio, 1969; Ibrahim et al., 1975). An idiopathic form of orthostatic hypotension, sometimes associated with tachycardia, is also known (MacLean et al., 1944; Scherba, 1954). Propranolol has been suggested (Miller et al., 1974) in the treatment of orthostatic hypotension on the assumption that beta-blockade, by reducing orthostatic tachycardia, would increase cardiac output and stabilise arterial pressure.

The present study was designed to assess the effects of propranolol administration in a hypertensive patient affected by orthostatic hypotension, with no pronounced tachycardia.

\section{Case report and methods}

A 62-year-old man was admitted to hospital because of hypertension and increasing weakness and lightheadedness on standing. Supine arterial pressure ranged between $170 / 110$ and $180 / 120 \mathrm{mmHg}$; on standing, the arterial pressure decreased to levels as low as $130 / 100 \mathrm{mmHg}$. Heart rate showed only a minimal increase in the upright position. A detailed evaluation, including thyroid and adrenal gland functions, disclosed no abnormality. Plasma renin values were $198 \mathrm{ng} / 100 \mathrm{ml}$. No significant amounts of catecholaminies or their metabolites were found in urine samples. The patient did not take hypotensives or any other drug before or during his stay in hospital.

According to Ibrahim (1975), a preliminary study was performed to verify the integrity of each of the individual components of the baroceptor reflex arch. This was done by testing changes in systemic blood pressure during hyperventilation, mental arithmetic, and cold pressor tests.

Thereafter, in the supine position, electrical impedance plethysmography was carried out on both legs of the subject, to derive a noninvasive index of blood flow. This plethysmographic method, described elsewhere (Nyboer, 1970; Nyboer et al., 1974), was chosen because, by surface impedance electrodes the segmental volemic conditions can be best defined without abnormal segmental compression, or crude air or water-tight encasement, always required for mechanical plethysmography. Electrocardiogram, phonocardiogram, and carotid pulse were recorded on an Electronics for Medicine photographic recorder; this was done in order to obtain systolic time intervals (STI), which cor- 
relate well with invasive indices of cardiac performance (Weissler et al., 1961; Metzer et al., 1970). Arterial pressure was measured simultaneously by a cuffed manometer and heart rate was derived from the electrocardiogram. All these recordings were then repeated with the patient in the standing position.

Subsequently, propranolol (10 mg) was administered intravenously and the entire procedure was repeated both in the supine and upright position.

Finally, 3 hours after the administration of the drug, when heart rate and arterial pressure had returned to previous values, a temporary transvenous cardiac pacemaker was implanted and the procedure was repeated at a constant heart rate of 130 beats/min before and after a new dose of propranolol $10 \mathrm{mg}$ intravenously. Left ventricular ejection time (LVET), LVET corrected for heart rate (LVETc) (Weissler et al., 1969), pre-ejection period (PEP), and isometric contraction time (ICT) were calculated according to the methods of Py and Meurin (1971); in order to quantify the changes in the plethysmographic waves, the Jantsch index was calculated for each tracing (Jantsch, 1958). In order to assess the reproducibility of the results, the study was repeated after 48 hours.

Written consent was obtained from the patient before the study.

\section{Results}

The preliminary tests indicated that the lesion was at the periphery of the baroceptor reflex arch, since abnormal responses were measured during all of the tests (Table).

\section{SINUS RHYTHM}

\section{Before propranolol}

Arterial pressure, which was $175 / 115 \mathrm{mmHg}$ in the supine position, decreased to $130 / 100 \mathrm{mmHg}$ when
Table Effect of tests of autonomic function on arterial pressure in a patient with orthostatic hypotension

\begin{tabular}{llll}
\hline & \multicolumn{3}{l}{ Blood pressure $(\mathrm{mm} \mathrm{Hg})$} \\
\cline { 2 - 4 } & Systolic & Diastolic & Mean \\
\hline Supine & 175 & 115 & 135 \\
Tilt up & 130 & 100 & 110 \\
Cold pressor test & 165 & 110 & $128 \cdot 3$ \\
Mental arithmetic & 160 & 100 & 120 \\
Hyperventilation & 165 & 100 & $121 \cdot 5$ \\
\hline
\end{tabular}

upright, while heart rate rose from 95 to 98 beats $/ \mathrm{min}$ (Fig. 1). The LVETc decreased from 392 to $386 \mathrm{~ms}$ c on standing. PEP and ICT remained unmodified 음 (100 and $20 \mathrm{~ms}$, respectively). The postural change induced an increase in Jantsch's index in both legs, $T$ from 0.70 to 0.94 in the right and from 0.76 to 0.95 in the left limb (Fig. 1).

\section{After propranolol}

Arterial pressure showed minimal change from supine $(170 / 110 \mathrm{mmHg})$ to standing position $(175 / 110 \mathrm{mmHg})$ and heart rate increased from 82 to 92 beats/min (Fig. 1). LVETc was prolonged from 371 to $377 \mathrm{~ms}$. No change was seen in PEP and ICT (110 and $30 \mathrm{~ms}$, respectively). The Jantsch index decreased in both legs, from 0.66 to 0.55 and from 0.70 to 0.60 in the right and left leg, respectively (Fig. 1).

\section{DURING ATRIAL PACING}

\section{Before propranolol}

Arterial pressure decreased from $180 / 120$ to $130 / 100$ $\mathrm{mmHg}$ on standing (Fig. 2); LVETc decreased from 408 to $393 \mathrm{~ms}$ and PEP and ICT were unchanged (130 and $30 \mathrm{~ms}$, respectively). The Jantsch index rose in both legs in the erect position from 0.63 to 0.75 in the right leg and 0.70 to 0.87 in the left leg (Fig. 2).

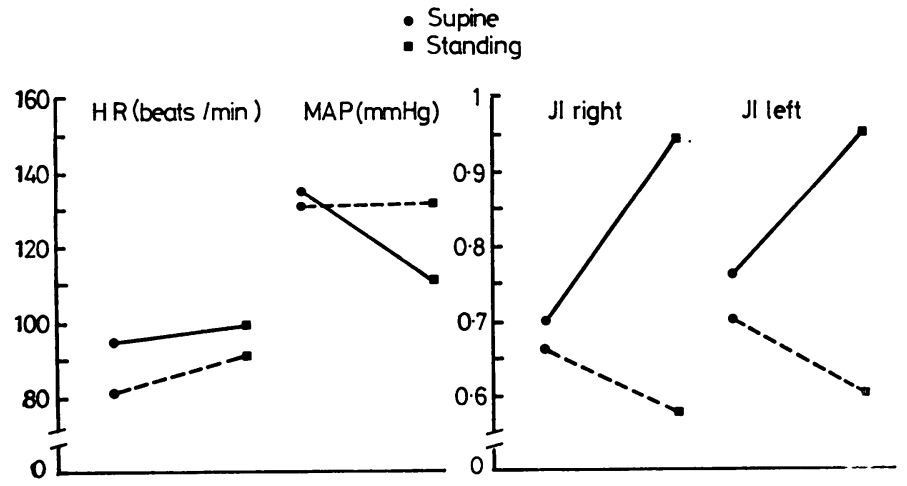

Fig. 1 Effects of standing on heart rate $(H R)$, mean arterial pressure $(M A P)$, and fantsch index $(\mathcal{F})$ in the left and right leg, before (solid line) and after (dotted line) propranolol (10 mg i.v.). 


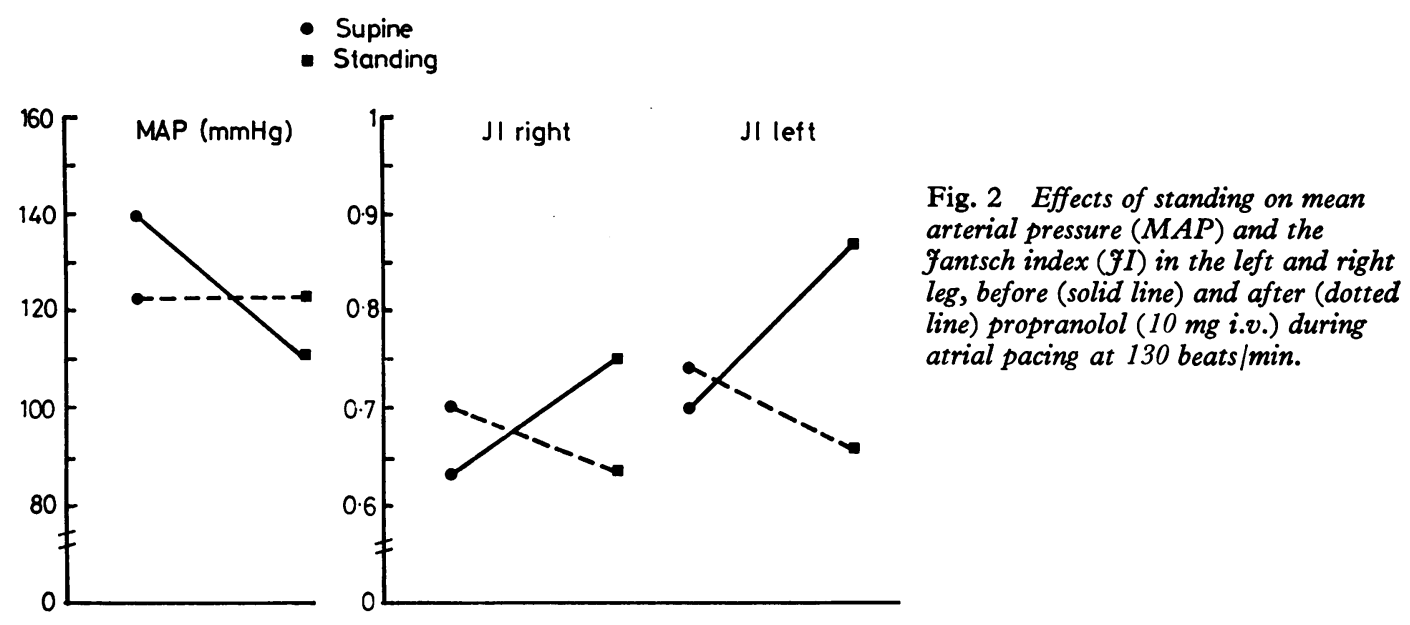

\section{After propranolol}

Arterial pressure was $150 / 110 \mathrm{mmHg}$ in the supine position and on standing (Fig. 2). LVETc was prolonged from 408 to $418 \mathrm{~ms}$ while PEP was $130 \mathrm{~ms}$ in the supine and upright position and ICT was $30 \mathrm{~ms}$ in both positions. The Jantsch index decreased from 0.70 to 0.63 in the right leg and 0.74 to 0.66 in the left (Fig. 2). The entire procedure was repeated after 48 hours and very similar results were obtained.

\section{Discussion}

Propranolol has recently been suggested for treating orthostatic hypotension since its effects on heart rate could normalise cardiac output impaired by orthostatic tachycardia (Miller et al., 1974).

The patient studied in this report showed distinct hypotension on standing. This was accompanied by a modest increase in heart rate. Moreover, in the upright position there was an increase in flow in the peripheral vascular bed, as reflected by a rise in the Jantsch index.

The change in posture was not accompanied by any discernible change in stroke volume, as shown by the minimal change in LVETc. This observation rules out the possibility that the observed hypotension is dependent on a decrease in cardiac output. It indicates that the increase in the Jantsch index could be related only to peripheral vasodilatation, which takes the place of the normal postural vasoconstriction.

During atrial pacing at 130 beats per minute similar results were obtained, thus showing that an increase in heart rate will not modify this response.

Propranolol administration can inhibit the decrease in arterial pressure on standing. This event is accompanied by a small increase in LVETc and normal postural vasoconstriction as shown by the decrease in the Jantsch index. Similar results were observed during atrial pacing, thus showing that the stabilising effects of beta-blockade on arterial pressure are not related to reduced heart rate. Propranolol administration modified the vasodilatation induced by posture change, restoring the normal vasoconstrictive response. As a consequence, the abnormal reflex response in the peripheral vascular bed seems to be the haemodynamic factor responsible for the reduction in arterial pressure with upright posture. This conclusion is in agreement with a previously reported hypothesis (Ibrahim et al., 1974), as well as recent studies suggesting that lesions in the efferent sympathetic pathways are the predominant findings in orthostatic hypotension (Ibrahim et al., 1975). On the other hand, other studies have shown the participation of both alpha- and beta-receptors in the regulation of posture related arterial reflexes (Rengo et al., 1976). Accordingly, the orthostatic hypotension in this patient could be the result of a disturbance of balance in the peripheral sympathetic nervous system, caused by peripheral beta-receptor hypersensitivity, or by alpha-receptor fatigue (Luria et al., 1964).

In conclusion, the beta-receptor blockade induced in this patient seems to allow the action of catecholamines mainly on the alpha receptors, thus restoring the normal postural vasoconstriction.

\section{References}

Boźović, L., Castenfors, J., and Orö, L. (1970). Plasma renin activity in patients with disturbed sympathetic vasomotor control (postural hypotension). Acta Medica Scandinavica, 188, 385-388. 
Drenick, E. J. (1957). Orthostatic hypotension in the presence of hypertensive cardiovascular disease. Annals of Internal Medicine, 47, 124-131.

Ibrahim, M. M. (1975). Localization of lesion in patients with idiopathic orthostatic hypotension. British Heart Fournal, 37, 868-872.

Ibrahim, M. M., Tarazi, R. C., and Dustan, P. H. (1975). Orthostatic hypotension: mechanisms and management. American Heart fournal, 90, 513-520.

Ibrahim, M. M., Tarazi, R. C., Dustan, P. H., and Bravo, E. L. (1974). Idiopathic orthostatic hypotension: circulatory dynamics in chronic autonomic insufficiency. American fournal of Cardiology, 34, 288-294.

Jantsch, H. (1958). Zur Auswertung des peripheren Rheograms. Wiener medizinische Wochenschrift, 45, 1004-1009.

Lewis, H. D., Jr., and Dunn, M. (1967). Orthostatic hypotension syndrome. American Heart fournal, 74, 396-401.

Luria, M. H., Miller, A. J., and Benjamin, M. K. (1964). Successful therapy of prolonged hypotension with an adrenergic beta-receptor blocking agent. Circulation, 29, 494-498.

MacLean, A. R., Allen, E. V., and Magath, T. B. (1944). Orthostatic tachycardia and orthostatic hypotension: defects in the return of venous blood to the heart. American Heart Fournal, 27, 145-163.

Metzer, C. C., Chough, C. B., Kroetz, F. W., and Leonard, J. J. (1970). True isovolumetric contraction time: its correlation with two external indexes of ventricular performance. American fournal of Cardiology, 25, 434-442.

Miller, A. J., Cohen, C. H., and Glick, G. (1974). Propranolol in the treatment of orthostatic tachycardia associated with orthostatic hypotension. American Heart fournal, 88, 493-495.

Nyboer, J. (1970). Electrical Impedance Plethysmography, 2nd ed. Charles C. Thomas, Springfield, Illinois.
Nyboer, J., Murray, P., and Sedensky, J. A. (1974). Bloodflow indices in amputee and control limbs by mutual electrical impedance plethysmography. American Heart Fournal, 87, 704-710.

Parra, J., and Vidrio, H. (1969). Drug effects on the blood pressure response to postural changes in the unanesthetized rabbit. Archives Internationales de Pharmacodynamie et de Thérapie, 181, 353-362.

Py, J., and Meurin, J. (1971). Phonocardiographie Clinique et Mécanocardiographie. J. B. Ballière, Paris.

Rengo, F., Brevetti, G., Ferro, G., De Caprio, L., Trimarco, B., and Critelli, G. (1976). Ruolo del sistema adrenergico nella genesi dei riflessi posturali arteriolari. In Atti LXXVI Congresso della Società Italiana della Medicina Interna. Pozzi Editore, Roma.

Scherba, E. J. (1954). Orthostatic hypotension and orthostatic tachycardia. American fournal of Medicine, 17, 880-886.

Sharpey-Schafer, E. P., and Taylor, P. J. (1960). Absent A circulatory reflexes in diabetic neuritis. Lancet, 1, 559-562.

Weissler, A. M., Harris, W. S., and Schoenfeld, C. D. (1969). Bedside technics for the evaluation of ventricular function in man. American fournal of Cardiology, 23, 577-583.

Weissler, A. M., Peeler, R. G., and Roehill, W. H., Jr. (1961). Relationships between left ventricular ejection time, stroke volume and heart rate in normal individuals and patients with cardiovascular disease. American Heart fournal, 62 367-378.

Requests for reprints to Dr Gregorio Brevetti, Istituto di Patologia Speciale Medica, II Facolta di Medicina e Chirugia, Via Sergio Pansini 5, 80131 Napoli, Italy. 